\title{
Historical perspectives of The American Association for Thoracic Surgery: Craig R. Smith
}

\author{
Tom C. Nguyen, MD, ${ }^{a}$ and Abe DeAnda, Jr, $\mathrm{MD}^{\mathrm{b}}$
}

Craig Richey Smith, Jr, the 92nd president of The American Association for Thoracic Surgery (AATS), was born in Cleveland, Ohio, on November 17, 1948, several days after incumbent Harry S. Truman defeated heavily favored Thomas E. Dewey. He was the second of 4 children born to 22-year-old parents, his namesake Craig Smith and Mary Glover Smith, a first-grade teacher. Smith's father started at the bottom rung of management in a Cleveland machine tool company while serving in the Navy Reserve. Smith spent much of his childhood on the move, and he quickly learned to adapt to change. In later years, the ease with which he embraced progress became a hallmark of his career as a leader and pioneer. During the Korean War, the family bounced across the continent, finally settling in Philadelphia, where he finished his senior year of high school at Harrington High. Smith excelled at football and was versatile playing multiple positions, including quarterback, running back, and safety. He also was accomplished at lacrosse, wrestling, and the long-jump.

In his early years, Smith's most influential role models were his grandparents. His grandfather, Donald Mitchell Glover, was a Harvey Cushing trainee and accomplished pediatric plastic surgeon, deeply revered by the family and community. He instilled in Smith the energy, love, and passion for patient care and hard work. His grandmother, Leona van Gorder Glover, was one of the first women of her generation to become a doctor. She was charismatic, lively, and independently wealthy because of the family-owned McKesson \& Robbins company. She introduced Smith and his brother to the outdoors, teaching them the art of fly-fishing and horseback riding.

In high school, Smith had a lackluster academic performance and was mislabeled an underachiever. Eventually, he was accepted to Williams College, where he was convinced that he was the "last student to be accepted." Worried about not graduating, Smith refused to buy mugs, T-shirts, or other collegiate memorabilia until after the first

\footnotetext{
From the Department of Cardiothoracic and Vascular Surgery, ${ }^{\mathrm{a}}$ The University of Texas Health Science Center at Houston, Houston, Tex; and Department of Cardiothoracic Surgery, ${ }^{\mathrm{b}}$ New York University School of Medicine, New York, NY. Disclosures: Authors have nothing to disclose with regard to commercial support. Received for publication March 28, 2013; accepted for publication Sept 5, 2013; available ahead of print Oct 15, 2013.

Address for reprints: Abe DeAnda, Jr, MD, Department of Cardiothoracic Surgery, NYU-Langone Medical Center, 530 First Ave, Suite 9V, New York, NY 10016 (E-mail: abe.deanda@nyumc.org).

J Thorac Cardiovasc Surg 2015;149:1-4

$0022-5223 / \$ 36.00$

Copyright (C) 2015 by The American Association for Thoracic Surgery http://dx.doi.org/10.1016/j.jtcvs.2013.09.003
}

semester. In his own words, he "worked like an animal, slept little, and learned to drink coffee." Smith excelled in the academic environment at Williams College and became a top student, graduating Phi Beta Kappa. Smith continued to play football and lacrosse at Williams until a summer injury his sophomore year. He worked several odd, even lifethreatening, jobs over the years and spent his early college summers at a steel mill shoveling coal in the coke plant at Alan Wood Steel Company in Norristown, Pennsylvania. The job was harsh and dangerous, reminding Smith of the underworld as people walked around with wooden shoes, hazmat suits, and masks while surrounded by dangerous flames. As a young man, he was unaware of the dangers of heat exhaustion and made nothing of his shivering in the $135^{\circ} \mathrm{F}$ inferno at first. Eventually it caught up to him. In the last 15 minutes of his last day of work one summer, delirium set in because of the heat, and his mind wandered. Before Smith knew what hit him, he was trapped between a lorry car used to dump coal and a brick wall, and then fell down an elevator shaft. He survived but had a broken pelvis and a bladder hematoma. He spent the rest of the summer recuperating in the hospital. The injury ended his collegiate athletic career.

During his final years of college, Smith was influenced by an intriguing genetics professor who taught him the value of experimental design and basic science. He learned how to critically review papers, break down design flaws, and appropriately evaluate scientific conclusions. This early experience undoubtedly contributed to his maturation into a respected clinical scientist and researcher. Smith was hooked and enrolled in a PhD program at Dartmouth with a focus on biophysics. His research projects ranged from "vitamin E and fertility of the male rotifer" to "mechanisms of olfaction," including studies on Phycomyces fungus. Within the first few weeks of graduate school, however, Smith confessed an "appalling misunderstanding of my own nature" with significant misgivings about his path as he laboriously counted male rotifers in petri dishes. He dropped out of the program after his second year and spent the next 14 months as a telephone lineman. His responsibilities included clearing lines, setting poles, and felling timber in the Vermont wilderness. Smith became adept at climbing trees and, to the best of our knowledge, is the only AATS president whose formative years included scaling 100-foot telephone poles (Figure 1). Smith's path to medicine was definitely circuitous. After his extensive experience as a toughened laborer and seemingly endless rumination over his eventual fate while playing the pipe organ in the Dartmouth College chapel, Smith was finally 


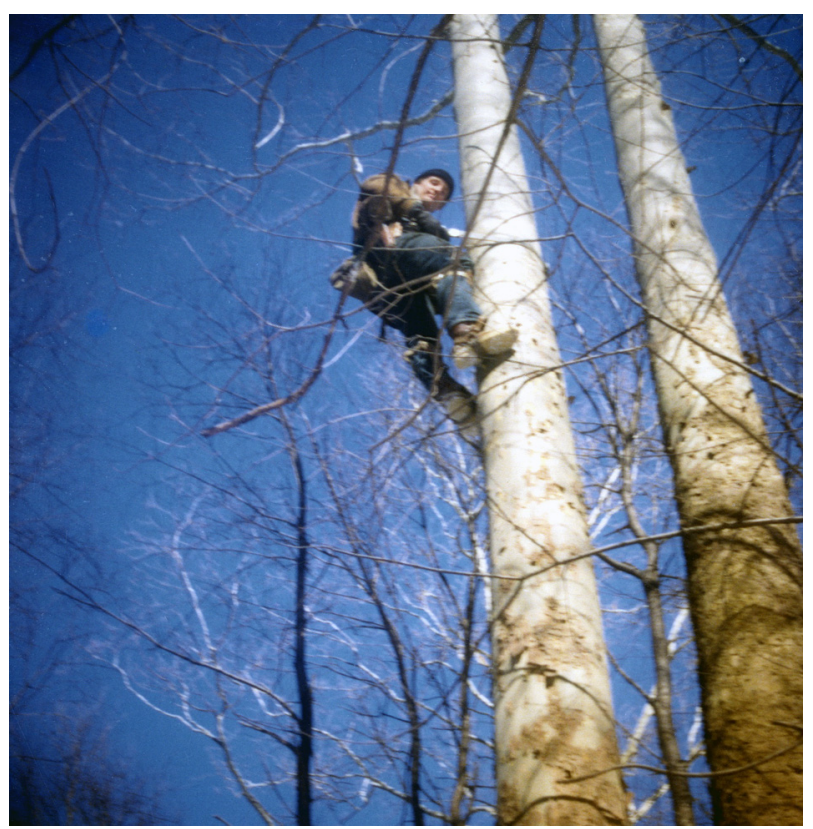

FIGURE 1. The future AATS president "climbing his way to the top."

accepted into medical school at Case Western Reserve in 1974.

Smith recalls his 4 years at Case Western to be the most uncomplicated and enjoyable years of his life. In 1977, he matched in general surgery at the University of Rochester and worked in Dr Seymour Schwartz's research laboratory. Smith still laments about an early experience in the laboratory when he was naïve to the world of publishing. $\mathrm{He}$ wrote an article with $\mathrm{Dr}$ Schwartz as the sole co-author, unwittingly snubbing his other colleagues, a slight he has remembered all these years. Near the end of his clinical training, Dr Schwartz encouraged Smith to consider Columbia Presbyterian for cardiothoracic surgery residency because of his connection with $\mathrm{Dr}$ Keith Reemtsma (71st AATS president). Smith recalls the program to be physically grueling but clinically rewarding, especially in the realm of valvular heart disease and congenital surgery.

After completion of his cardiothoracic surgery training at Columbia in 1984, Smith was recruited to join Drs James Malm (66th AATS president), Frederick Bowman, and Eric Rose on the Columbia faculty. In 1996 he became Chief of Cardiothoracic Surgery, and in 2007 he was promoted to Chairman of the Department of Surgery. During his tenure at Columbia, Smith has trained more than 35 general surgery residents and 43 cardiothoracic surgery residents and has co-authored more than 175 publications in peer-reviewed journals on topics of transplantation, coronary revascularization, and valve surgery. In addition, recognizing the importance of hybrid procedures and cross training, he orchestrated the first interventional cardiology fellowship designed for cardiothoracic surgeons and was the surgical principal investigator of the landmark Placement of Aortic Transcatheter Valve Trial (PARTNER) that demonstrated the safety of transcatheter aortic valve replacement. ${ }^{1}$

On April 31, 2012, Dr Smith presented his Presidential Address at the 92nd Annual Meeting of the AATS in San Francisco. ${ }^{2}$ The theme of his talk was derived from an AATS motto Smith coined, "We Model Excellence." Noting that the verb "to model" could denote the act of emulating or the process of creating, he explored how both processes were critical to the continuing growth and success of the field of cardiothoracic surgery generally and the AATS specifically. As an example of the creative model, he contrasted the format of the annual TransCatheter Therapeutics meeting with the AATS annual meeting, observing that the process of the AATS meeting begins with a rigorous peer review of abstracts resulting in less than a $10 \%$ acceptance rate. The process remains dynamic and selective as the data are presented, being commented on and discussed by moderators, selected discussants, audience members, and peers. Thus, all stakeholders play a role in the release of new techniques and information. This maintains the integrity of the process compared with meetings where the content is preselected and non-peer-reviewed, and the discussions are carefully choreographed.

Smith then expanded on a now familiar subject from his recent predecessors - the future of cardiothoracic surgery as a profession and the responsibility, concern, and hurdles of our community in attracting and training future generations of cardiothoracic surgeons. He acknowledged that it was not the quality of the surgeons in the pipeline that was concerning, stating "...the quality of the students applying to our new integrated programs convinces me that the kind of individuals who become great thoracic surgeons are still plentiful." His concern was more that resources were being used "...on improving the journey, not the destination, and ignores our much more fundamental failure to project an image of a future worth pursuing." $\mathrm{He}$ expressed his views on the 80-hour work week requirements while conceding that the days of 120-hour work weeks were not coming back. Rather, the structure of training should be adjusted and restructured, something akin to a structured apprenticeship where residencies were compressed and followed by a period of tutorial practice with a set time to obtain requirements for the board examination. Under this scenario, the assumption would be made that residents would be challenged externally by their mentors and internally by themselves.

He concluded by urging the profession to look beyond the day-to-day practice of cardiothoracic surgery and instead to encourage innovation and collaboration. By using transcatheter aortic valve replacement as an example of a 


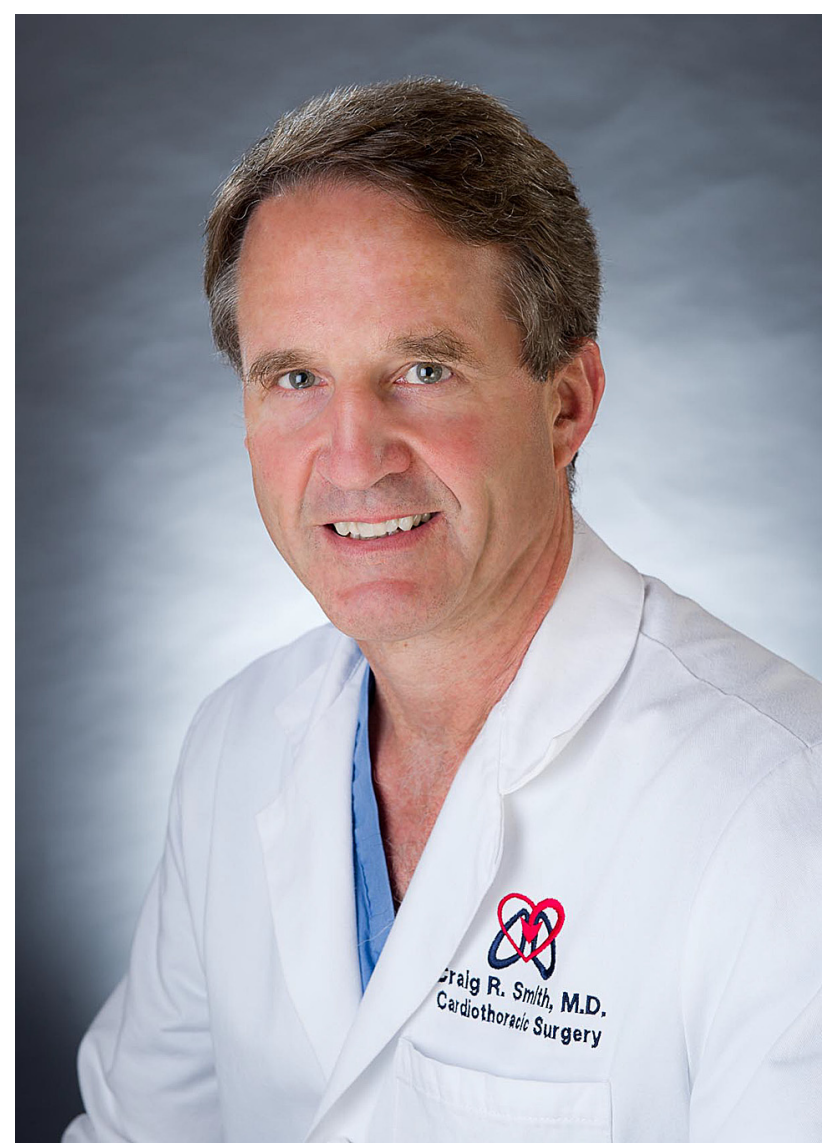

FIGURE 2. Dr Craig R. Smith.

collaborative effort with the potential of changing how we approach patients needing valvular replacement, he looked to the future offering innovations and revolutions in imaging technology as the next frontier. He encouraged not just the current practitioners of cardiothoracic surgery but "...the young men and women hiding in the back" to lead the way.

Those who know Craig Smith describe him as "ruggedly handsome with a boxer physique" (Figure 2). While some command attention by a loud decibel, a boisterous tie, or arrogant swagger, Smith draws attention by his calm and unassuming demeanor. When Dr Smith walks into a room, his presence is felt. Witty, laconic, and honest, he chooses his words carefully. His humor is deadpan with a dose of sarcasm. The Columbia residents are fond of saying that one can set one's watch by Dr Smith, and that they know it is 5:55 AM when they see him walk into the intensive care unit to round. Smith likes to say, "It's just as easy to always be 5 minutes early as it is to always be 5 minutes late."

Smith met his wife, Trish, when she was an exchange student at Vassar College during his junior year at Williams. They married shortly after he graduated during Labor Day weekend in 1970. His wife later turned down law school

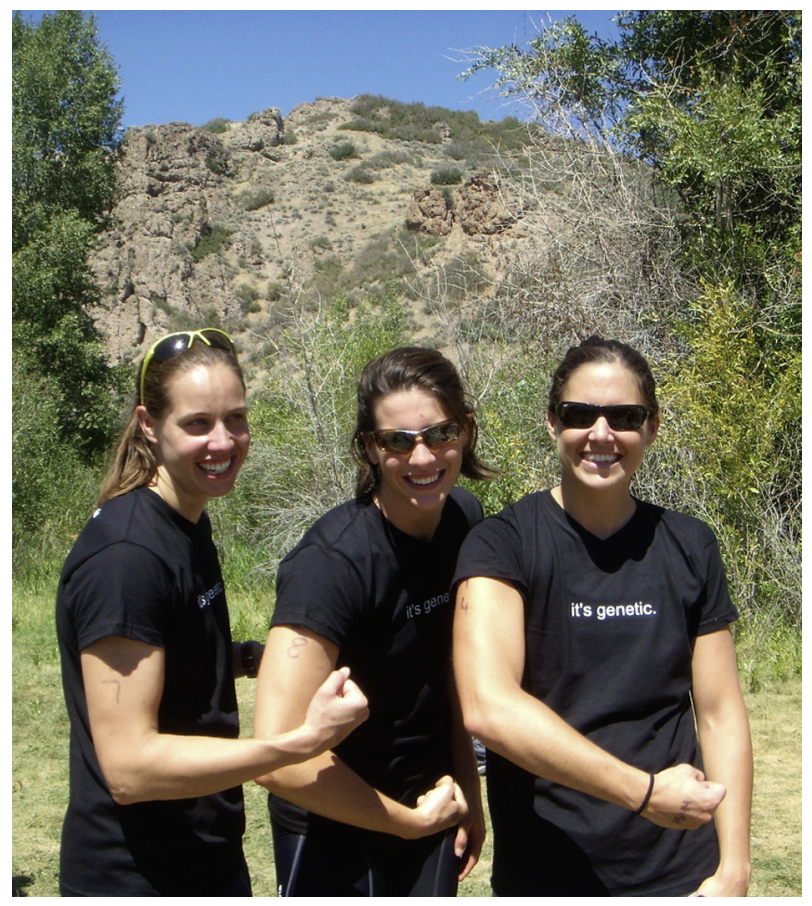

FIGURE 3. Craig and Trish's 3 daughters: Elizabeth, Halley, and Emily (left to right) after completing a marathon in Utah in 2007.

at the University of Virginia, following him to Cleveland, where she pursued a law degree from Case Western. Trish was an outstanding multisport athlete in high school (field hockey, basketball, lacrosse, and squash) and was invited to try out for the Olympic field hockey team, which she declined to attend college. She picked up running instead and soon became the best runner for the Atlanta women's team, was Nike supported, and was nominated for "Runner of the Year" by the New York Road Runners Club in 1982. She had a successful career as a lawyer and judge. Craig and Trish had 3 equally talented and athletic daughters (Figure 3). Emily was an All-American swimmer at Stanford and qualified for the Olympic Trials in 1996; she later pursued a career in law. Elizabeth skipped her junior year at Williams College to train with the US sculling team and went to the Sydney Olympics in 2000; she is now an investment banker in New York. Halley was a 4-year varsity athlete at Williams College in track and field while majoring in Chinese; she works for the Sandia National Laboratory in bioterror defense.

Although many know Dr Craig Smith as a technical master and respected academician, few are familiar with the ups and downs of his journey. Smith once said, "In cardiac surgery the highs are high and the lows are low. If you can't handle the lows, you don't deserve the highs." The grace and humility of his ascent and his inspiring nod to the "young men and women hiding in the back" during his AATS presidential address are true to character. To whom much is given, much is expected, and to his 
colleagues and trainees, Dr Smith's "model of excellence" exceeds the greatest of expectations.

The authors thank Dr Smith for providing photographs and background material for this work and for spending time with the authors in discussion. We acknowledge the following for their personal insight in preparing this profile: Michael Argenziano, Allan Stewart, Eric Weiss, Serguei Melnitchouk, Mark Russo,
George Comas, and Isaac George. We particularly appreciate the in-depth editorial review by Lori Soni.

\section{References}

1. Smith CR, Leon MB, Mack MJ, Miller DC, Moses JW, Svensson LG, et al. Transcatheter versus surgical aortic-valve replacement in high-risk patients. N Engl J Med. 2011;364:2187-98.

2. Smith CR. AATS 2012: "To model excellence" J Thorac Cardiovasc Surg. 2012; 144:749-58. 